\title{
Effect of rose extract treatment on soluble CCR5 and CXCR4 secretion by the endothelial cells in vitro
}

\author{
Mark Christopher Arokiaraj ${ }^{1, *}{ }^{(}{ }^{,}$Eric Menesson ${ }^{2}$
}

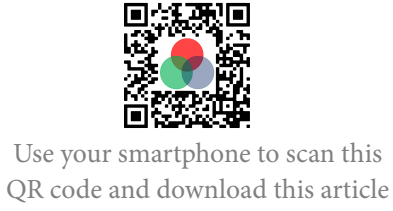

${ }^{1}$ Cardiology, Pondicherry Institute of Medical Sciences, Pondicherry, India

${ }^{2}$ Tebu Bio, France

Correspondence

Mark Christopher Arokiaraj, Cardiology, Pondicherry Institute of Medical Sciences, Pondicherry, India

Email: christomark@gmail.com

History

- Received: Feb 03, 2021

- Accepted: Apr 27, 2021

- Published: May 30, 2021

DOI : 10.15419/bmrat.v8i5.672

\section{Check for updates}

Copyright

(- Biomedpress. This is an openaccess article distributed under the terms of the Creative Commons Attribution 4.0 International license.

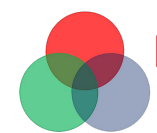

BioMedPress

The Open Access Publisher

\begin{abstract}
Background: CC-Chemokine Receptor 5 (CCR5) and Chemokine C-X-C-Motif Receptor 4 (CXCR4) are expressed in various tissues, and they are potential molecules involved in multiple pathways. CCR5 and CXCR4 targets are associated with immune regulation in patients in multiple tissues and numerous clinical conditions. The study was performed searching for a novel therapy for immune regulation on these CCR5 and CXCR4 receptors with rose extract. Methods: The crushed red rose extract was prepared, and it was processed for analysis. The HUVEC cells were obtained for seeding in the cell culture. The cells were tested in normal physiological conditions and varying degrees of hypoxia. The cells were treated with extract for 72 hours, and the resultant secreted supernatants were analyzed for expression of CCR5 and CXCR4 by the Elisa technique. Results: The CCR5 levels were significantly elevated at normoxia compared to untreated controls. The surge of CCR5 was persistent in 12\% hypoxia, and at higher degrees of hypoxia, the levels were mildly lower than the untreated levels. The CXCR4 levels were not changed in normoxia, and even with significant hypoxia, the levels were similar or mildly reduced compared to untreated values. Conclusion: The rose extract has the potentials to induce the secretion of soluble CCR5 from the HUVEC cells, and it can prevent the reduction of soluble CXCR4 levels during the hypoxic challenge of the endothelial cells. This in-turn can modulate the receptor levels on the endothelial cells, which has clinical applications.
\end{abstract}

Key words: CCR5, CXCR4, Immune regulation, Rose extract

\section{INTRODUCTION}

Immune-mediated disorders are common in clinical practice. Most clinical disorders - infective, inflammatory, or neoplastic have dys-regulation of immune function in the background. Autoimmune disorders, bacterial and viral infections, and even noncommunicable diseases are regulated to various extents by the immune system. Though many treatment methods are available for immune dys-regulation, there are disadvantages and potential side effects of the existing therapy. This includes steroids and other common immunomodulators, especially when used in long-term or immunocompromised patients.

The study was performed searching for a novel immune regulation agent, which can modulate the immune system without potential side effects. CXCR4 and CCR 5 are surface proteins related to prospective heterogeneous multi-functional properties with essential functions in the immune system, including autoimmune disorders and malignancies ${ }^{1-5}$. The study was performed in search of a novel therapy for immune regulation using rose extract.

CCR5 and CXCR4 are associated with immune regulation in human retrovirus-infected patients ${ }^{1-3}$.
Blocking of these receptors prevents internalization of the viruses, and in turn, it is associated with resistance to infection. The genetic polymorphism in the receptors can also be associated with overwhelming infections like West Nile fever. In drug-induced inhibition of the receptor, this is not seen as a side effect $^{6}$. The secretion of CCR 5 further influences the CCR5 and CXCR4 receptor's expression. If the CCR5 levels are more, they inhibit the receptors by blocking the receptors expressed on Tlymphocytes and the immune system. Hence, in his study, the effect of the extract on the expression of the receptors CCR 5 and coreceptor CXCR4 was studied in normal and hypoxic conditions. These receptors are also associated with cardiovascular, tumor development, and nervous system changes. Newer medications are available in the treatment of human retrovirus infections ${ }^{7}$. However, most of these are associated with significant side effects in the long term. Also, an effective CCR5 and CXCR4 blockage are related to various clinical benefits. Rose extract has minimal stimulatory effects on $\mathrm{CD}^{+}{ }^{+}$T lymphocytes ${ }^{8}$.

Both CXCR4 and CCR5 are small transmembrane proteins with G-protein coupling, and therefore secretion is not expected in plasma. However, secreted 
forms of CXCR4 and CCR5 in plasma have been described in the past in literature ${ }^{9,10}$; in the setting of human immunodeficiency virus infections.

\section{METHODS}

\section{Preparation of red-rose extract}

A red rose (Rosa Rosacea) was taken from a plant in a red-rose garden supervised by a botanist. $2091 \mathrm{mg}$ of freshly collected petals were distributed in 6 Precellys CK14 lysing tubes (Bertin Technologies, ref. 03961-1003) to homogenize soft tissue. One $\mathrm{ml}$ of PBS (ThermoFisher, ref. 14190) was added to each tube. The tubes were run on Precellys 24 homogenizer at 5000 $\mathrm{rpm}$ for 2 x 30 seconds. Then, the supernatant from all tubes was gathered and spun down at $200 \mathrm{~g}, 4^{\circ} \mathrm{C}$, for $5 \mathrm{~min}$. The supernatant was spun down twice at 4 ${ }^{\circ} \mathrm{C}$ for $5 \mathrm{~min}$, the first at $2000 \mathrm{~g}$ and the last at $10000 \mathrm{~g}$. The final supernatant was $0.22 \mu \mathrm{m}$ filtered (Sartorius, ref. $16534-\mathrm{K})$ and stored until use at $-20{ }^{\circ} \mathrm{C}$.

\section{Treatment of HUVEC cells}

HUVEC, which was commercially available (Human Umbilical Vein Endothelial Cells -Cell Applications, ref. 200-05n, lot 3054) was procured, and subcultures were performed. HUVEC cells were seeded at passage 8 in 48 -well plates at 9.500 cells/well $\left(10000\right.$ cells $\left./ \mathrm{cm}^{2}\right)$ in $250 \mu \mathrm{L}$ of endothelial cell growth medium (Cell Applications, ref. 211-500). $24 \mathrm{~h}$ after plating, the cells were treated in duplicate with $250 \mu \mathrm{L}$ of red rose extract diluted at $0.5 \%, 0.05 \%$, and $0.005 \%(\mathrm{v} / \mathrm{v})$ in endothelial cell growth medium (Cell Applications, ref. $211-500$ ) or with growth medium only as of the control for $72 \mathrm{~h}$ at $21 \%, 12 \%, 5 \%$, and $1 \% \mathrm{O}_{2}$. Our previous study showed cytotoxicity of the rose extract at dilutions of about $>0.5 \%$ by microscopic analysis.

The hypoxia INVIVO2 workstation (Baker Ruskinn) was used to simulate hypoxia conditions at $12 \%, 5 \%$, and $1 \% \mathrm{O}_{2}$. At each of these lower oxygen levels, the medium incubated on cells was previously preconditioned with the HypoxyCOOL device (Baker Ruskinn). The duplicate cell culture medium of each different condition was collected and pooled after 72 h. The cell viability was evaluated under a microscope. The collected medium samples were stored at $-80{ }^{\circ} \mathrm{C}$ for the profiling of secreted cytokines.

\section{CCR5 evaluation}

For the evaluation, the standard Abbkine Human CC-Chemokine Receptor 5 (CCR5) ELISA Kit (Ref. KTE62546) was used. The samples tested were diluted at $1 / 5$ in monoplicate. This Human CCChemokine Receptor 5 (CCR5) ELISA Kit employs a two-site sandwich ELISA to quantitative CCR5 in samples ${ }^{11-14}$. An antibody specific for CCR5 has been pre-coated onto a microplate. Standards and samples were pipetted into the wells, and the immobilized antibody binds any CCR5 present. After removing any unbound substances, a biotin-conjugated antibody specific for CCR5 was added to the wells. After washing, Streptavidin conjugated Horseradish Peroxidase (HRP) was added to the wells ${ }^{13}$. Following a wash to remove any unbound avidin-enzyme reagent, a substrate solution was added to the wells, and color develops in proportion to the amount of CCR5 bound in the initial step ${ }^{15}$. The color development was stopped, and the intensity of the color was measured.

\section{CXCR4 evaluation}

The kit used was obtained from Elabscience Human CXCR4 (Chemokine C-X-C-Motif Receptor 4) ELISA Kit (Ref. E-EL-H5490). The samples tested were undiluted in monoplicate. This ELISA kit uses the standard Sandwich-ELISA principle ${ }^{14,16}$. The microELISA plate provided in this kit has been pre-coated with an antibody specific to Human CXCR4. Standards or samples are added to the micro ELISA plate wells and combined with the specific antibody. Then a biotinylated detection antibody specific for Human CXCR4 and Avidin-Horseradish Peroxidase (HRP) conjugate were added successively to each microplate well and incubated. Free components were washed away. The substrate solution was added to each well. Only those wells that contain Human CXCR4, biotinylated detection antibody, and Avidin-HRP conjugate will appear blue. The addition of the stop solution terminated the enzyme-substrate reaction, and the color turns yellow. The optical density (OD) is measured spectrophotometrically at a wavelength of $450 \mathrm{~nm} \pm 2 \mathrm{~nm}$. The OD value is proportional to the concentration of Human CXCR4. The calculation of the concentration of Human CXCR4 in the samples was made by comparing the OD of the samples to the standard curve.

\section{RESULTS}

\section{CCR5}

All samples were tested diluted at 1/5 in monoplicate (one well per sample). Using diluted human CCR5 standard at $320 ; 160 ; 80 ; 40 ; 20$, and $10 \mathrm{pg} / \mathrm{ml}$, a standard curve was drawn by calculating a 4 parameters logistic regression (Figure 1). The coefficient of determination $\mathrm{R}^{2}$ is over 0.999 . The minimum detectable dose of Human CCR5 is typically less than $1 \mathrm{pg} / \mathrm{ml}$. 
The regression shows the calculation of the concentrations of CCR5 in samples (Table 1and Figures 2 and 3). The CCR5 concentrations were elevated with rose extract treatment. The rise in the CCR5 levels was preserved in normoxia and treatment at $12 \% \mathrm{O}_{2}$. The increase in CCR5 was seen at all the rose extract $0.005 \%, 0.05 \%$, and at a level of $0.5 \%$. Predominantly the increase was observed at treatment with $21 \%$ and $12 \%$ oxygen. At lower oxygen saturation of $5 \%$ and $1 \%$, the secretion was reduced at all concentrations of the rose extract (Panels A and B, Figure 3). Compared to treatment at $21 \%$ oxygen saturation, $12 \%$ had higher values of CCR 5 at all concentrations of the rose extract (Panel C, Figure 3). Table 1 shows the highest values of changes with treatment at $0.005 \%$ rose extract concentration. There was no change or reduction in CCR5 values when treated with severe hypoxia ( $5 \%$ and $1 \% \mathrm{O}_{2}$ ) irrespective of the rose extract concentration. In severe hypoxia-treated samples, the levels of CCR5 were reduced compared to untreated levels.

\section{CXCR4}

All samples were tested undiluted in monoplicate (one well per sample). Using diluted human CXCR4 standard at $5000 ; 2500 ; 1250 ; 625 ; 312.5 ; 156.25$, and 78.13 $\mathrm{pg} / \mathrm{mL}$, a standard curve was drawn by calculating a four parameters logistic regression (Table 2, Figures 4 and 5). The coefficient of determination $R^{2}$ is over 0.999. The CXCR4 levels were similar to the untreated levels at normoxia and 12\% oxygen levels. However, unlike CCR5 values, in severe hypoxia, the levels of CXCR4 were preserved compared to normoxia levels. There was a minimal increase in the levels of CXCR4 at $12 \% \mathrm{O}_{2} \quad 0.005$ percent rose extract concentration and at $5 \% \mathrm{O}_{2}$ concentration $-0.5 \%$ rose extract treatment. The minimal increase in the CXCR4 was also observed at $5 \% \mathrm{O}_{2} \quad 0.5 \%$ rose extract (Panels A and B, Figure 5). There was a decrease in the levels of CCR5 compared to values at $21 \% 0_{2}$ when treated at 12,5 and $1 \% \mathrm{O}_{2}$ levels (Panel C, Figure 5). Table 2 shows only minimal elevations in CXCR4 levels at $0.005 \%+$ $12 \% \mathrm{O}_{2}$ treatment and $0.5 \%+5$ and $1 \% \mathrm{O}_{2}$.

\section{DISCUSSION}

The study shows high levels of CCR5 after rose treatment, whereas the CXCR4 levels were maintained in normoxia conditions, and the CXCR4 levels were elevated in hypoxic conditions after rose treatment. CCR5 and CXCR4 act as co-receptor for the entry of the virus inside the endothelial and immune regulatory cells. Blocking of these receptors is known to delay the manifestations of the disease. Therefore, CCR5 or CXCR4 genetic mutations are associated with resistance or delay in clinical disease manifestation at the population level after retrovirus infection. Hence, this observation can help treat immunodeficiency disorder or reduce the manifestations of the disease.

The secretion by endothelial cells could result from cell lysis based as it is a transmembrane protein. CXCR4 is $45 \mathrm{kDaltons}^{17}$ and the molecular weight of CCR5 is $40 \mathrm{kDaltons}{ }^{18}$. The predicted molecular weight of these would fall in the category of middle molecules comparable by size with Beta 2 microglobulins, cystatins, complement factors, etc ${ }^{19}$. In our previous study, we have shown that cell lysis does not happen with rose extract concentrations $<0.1$ percent $^{20}$. Our observations in this study have shown that the secretion was observed at much lesser concentrations. Hence, the observations cannot be attributed to cell damage or lysis as the mechanism.

It has been demonstrated that the CCR 5 and CXCR4 receptors could be blocked by CCR5 or CXCR4 molecules by the phenomenon of competitive antagonism $^{21}$. Many selective agonists, both peptide and non-peptide molecules, have consistently shown internalization of the receptors after binding to the CCR5 receptors ${ }^{22-24}$. CCL5 or RANTES is a close molecule associated with the binding of the CCR5 receptors, and non CCL5 mechanisms are also involved in activating the CCR5 axis. In blocking the receptors, the agonist binds and internalizes the receptors and acts similar to the antagonist. This mechanism is also demonstrated distinctively in CXCR4 receptors ${ }^{25-27}$. It has been consistently shown that the retrovirus entry into the target cells is mediated through CXCR4 and CCR 5 co-receptors ${ }^{1-3}$. It has also been shown that the CCR5 inhibitor maraviroc to have clinical benefits by delaying the progression of the disease and its complications in achieving this effect by its inhibition $^{7}$. The results need to be tested and validated in animal and human studies in the future.

CCR5 is consistently shown to stimulate angiogenesis in the cancer tissues ${ }^{28,29}$. There is a close crosstalk between CCR 5 and immune system defense. In our previous study, the rose extract has shown an inhibitory action on IL2, IL1, TNF beta, and certain other vascular inflammatory markers ${ }^{30}$. RANTES is associated with stimulation of angiogenesis by CCR 5 mediated response ${ }^{31}$. The CCR5 is actively involved in mobilizing the polymorphonuclear myeloid cells into the blood and directing them to the tumors ${ }^{32}$. Hence, inhibition of the receptors could effectively result in the delay of tumor growth.

CCR5 is involved in cardiac fibrosis processes, especially in Chagas disease, and also antibodies to CCR5 
A

Incubation of standards and samples for $45 \mathrm{~min}$ at 37 degree $\mathrm{C}$

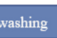

Incubation with HRP-conjugated detection antibody for $30 \mathrm{~min}$ at 37 degree $\mathrm{C}$

washing

Incubation with substrate reagent for $15 \mathrm{~min}$ at 37 degree $\mathrm{C}$

B

Incubation of standards and samples for $1.5 \mathrm{hr}$ at 37 degree C

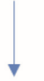

Incubation with biotinylated antibody for $1 \mathrm{hr}$ at 37 degree $C$

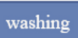

washing

Incubation with HRP conjugate for $30 \mathrm{~min}$ at 37 degree $\mathrm{C}$

Incubation with substrate reagent for $15 \mathrm{~min}$ at 37 degree $C$

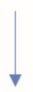

Addition of stop solution to stop reaction. Absorbance reading at $450 \mathrm{~nm}$

Figure 1: The figure shows the workflow evaluating CCR5 and CXCR4 levels by Elisa. 
Table 1: Results of human CCR5 ELISA testing which shows CCR5 concentration, absorbance observed at various oxygen concentrations, and the percentage change observed

\begin{tabular}{|c|c|c|c|c|c|c|c|}
\hline \multirow[b]{2}{*}{$\begin{array}{l}\text { Oxygen } \\
\text { level } \\
(\%)\end{array}$} & \multirow[b]{2}{*}{$\begin{array}{l}\text { Rose } \\
\text { extract } \\
\text { concen- } \\
\text { tration } \\
(\%)\end{array}$} & \multirow[b]{2}{*}{$\begin{array}{l}\text { Absorbance } \\
\text { without } \\
\text { blank } \\
(450 \mathrm{~nm})\end{array}$} & \multirow[b]{2}{*}{$\begin{array}{c}\text { CCR5 } \\
\text { concentration in } \\
\text { diluted samples } \\
(\mathbf{p g} / \mathrm{ml})\end{array}$} & \multirow[b]{2}{*}{ Dilutio } & \multirow[b]{2}{*}{$\begin{array}{l}\text { CCR5 con- } \\
\text { centration } \\
(\mathrm{pg} / \mathrm{mL})\end{array}$} & \multicolumn{2}{|c|}{$\begin{array}{l}\text { Change } \\
\text { Percentage }\end{array}$} \\
\hline & & & & & & $\begin{array}{c}\text { Treated } \\
\text { vs. untreated } \\
(\%)\end{array}$ & $\begin{array}{c}\text { Hypoxia vs. } \\
21 \% \mathrm{O}_{2} \\
(\%)\end{array}$ \\
\hline 21 & 0 & 0.214 & 16.02 & 5 & 80.12 & $100 \%$ & $100 \%$ \\
\hline 12 & 0 & 0.314 & 21.86 & 5 & 109.31 & 100 & 136.4 \\
\hline 21 & 0.5 & 0.281 & 19.96 & 5 & 99.82 & 124.6 & 100 \\
\hline 12 & 0.5 & 0.457 & 29.77 & 5 & 148.87 & 136.2 & 149.1 \\
\hline 21 & 0.05 & 0.358 & 24.36 & 5 & 121.78 & 152 & 100 \\
\hline 12 & 0.05 & 0.507 & 32.48 & 5 & 162.42 & 148.6 & 133.4 \\
\hline 21 & 0.005 & 0.585 & 36.7 & 5 & 183.5 & 229 & 100 \\
\hline 12 & 0.005 & 0.65 & 40.14 & 5 & 200.71 & 183.6 & 109.4 \\
\hline 5 & 0 & 0.379 & 25.5 & 5 & 127.49 & 100 & 159.1 \\
\hline 1 & 0 & 0.509 & 32.6 & 5 & 162.99 & 100 & 203.4 \\
\hline 5 & 0.5 & 0.269 & 19.27 & 5 & 96.35 & 75.6 & 96.5 \\
\hline 1 & 0.5 & 0.26 & 18.76 & 5 & 93.79 & 57.5 & 94 \\
\hline 5 & 0.05 & 0.225 & 16.69 & 5 & 83.43 & 65.4 & 68.5 \\
\hline 1 & 0.05 & 0.235 & 17.28 & 5 & 86.41 & 53 & 71 \\
\hline 5 & 0.005 & 0.282 & 20.02 & 5 & 100.1 & 78.5 & 54.6 \\
\hline 1 & 0.005 & 0.362 & 24.55 & 5 & 122.75 & 75.3 & 66.9 \\
\hline
\end{tabular}

are associated with the reversal of fibrosis ${ }^{33-35}$. It is also implicated in neointimal proliferation and vascular injuries ${ }^{36,37}$. Inhibition of the CCR5 is associated with the reversal of autoimmune myocarditis in bench studies ${ }^{38}$. Blocking the CXCR4 was associated with increased contractility and reduced inflammation-mediated injuries ${ }^{39}$. CCR4 blockage reduces atherosclerosis by reducing arterial injury 40 . CCR5 and CXCR4 inhibitions are involved in the positive remodeling of the myocardium after myocardial infarctions ${ }^{41,42}$.

CCR5 inhibition or polymorphisms is associated with reduced mortality in dialysis patient ${ }^{43}$ and reduced mucosal inflammation in murine colitis ${ }^{44}$. In the previous study, rose extract has been shown to inhibit inflammation markers significantly, including RANTES $^{20}$. CCR5 inhibitors block heat shock protein associated with HIV and inflammatory bowel diseases ${ }^{45}$ and reduce IL13 induced injuries ${ }^{46}$. CCR5 is an active target receptor for inhibition in the therapy of pulmonary arterial hypertension ${ }^{47,48}$. CXCR4 inhibition also was independently shown to have an attenuation of pulmonary arterial hypertension ${ }^{49,50}$.

Downregulation of CXCR4 is associated with alleviating pain ischemia-reperfusion-induced spinal cord injuries due to TLR4 inhibition ${ }^{51}$. CCR5 receptors are also expressed in the central nervous system by the neuronal, endothelial, and immune regulatory cells ${ }^{52}$. CCR5 axis is involved in Alzheimer's disease $^{53,54}$ CNS infections ${ }^{52}$, and blood-brain barrier maintenance during stroke recovery ${ }^{55}$. They are associated with neuronal survival in stroke therapy ${ }^{56}$. Recent SARS-CoV-2 infections are associated with high morbidity and mortality. The spike protein of SARS-CoV-2 has been associated with genomic sequences with overlaps in HIV-gp 120 protein, which could be a mutation by the natural evolution of viruses ${ }^{57}$. This could also be a random association of genomic sequences. Nevertheless, the pathophysiology of the SARS CoV-2 is still not well understood. If 


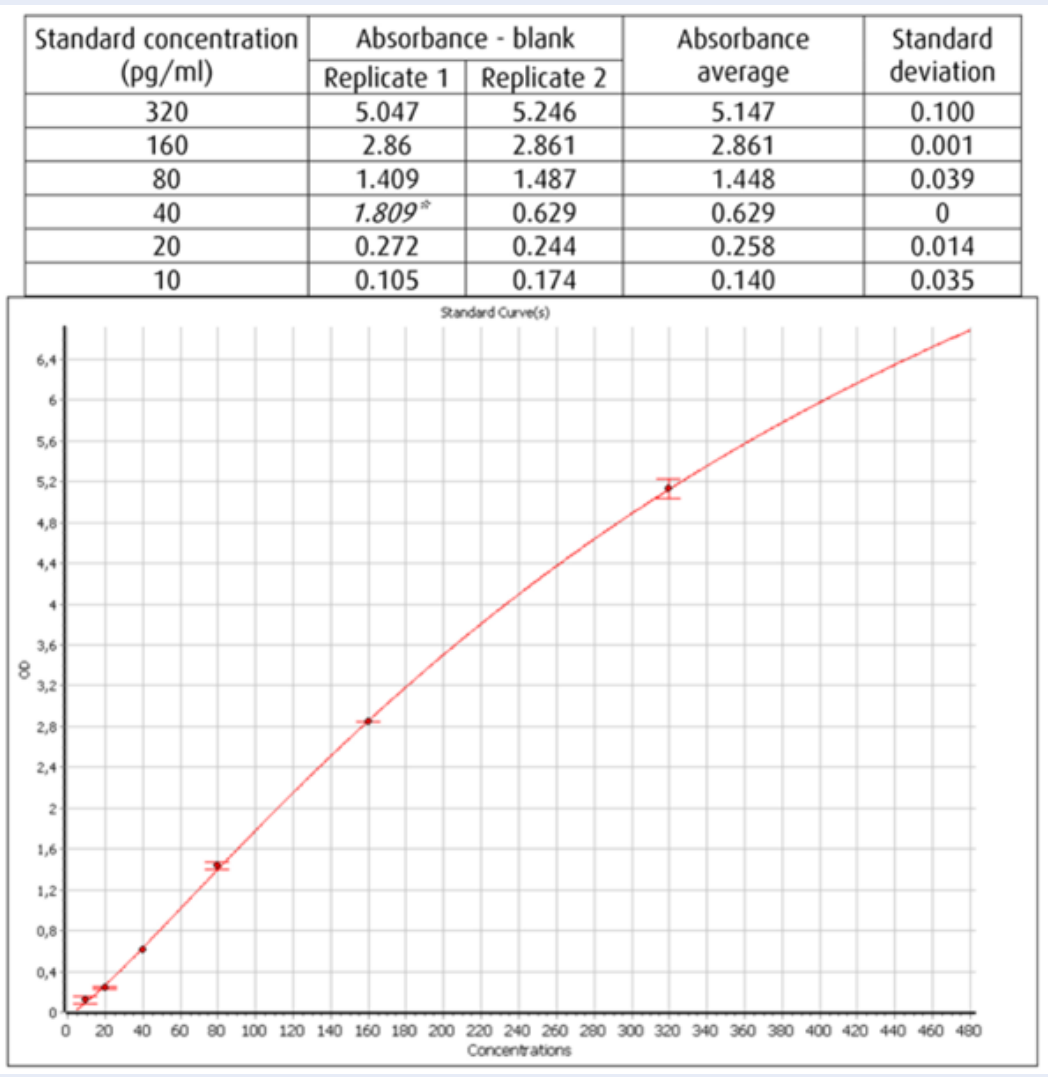

Figure 2: Standard curve of Human CCR5 ELISA. Standard curve of Human CCR5 ELISA assay which shows the standard CXCR4 concentration values against absorbance observed at $21 \% \mathrm{O}_{2}$. The standard value $\left(^{*}\right)$ was excluded from calculation of the regression.

this utilizes a CCR5 pathway with versatile functions, blocking the receptors could be helpful, though this is speculative.

CCR5 and CXCR4 are transmembrane receptors, and the mechanism of secretion into the plasma is not very clear. In the past, soluble CCR5 and CXCR4 receptors are observed in the plasma ${ }^{58,59}$. Also, in the past recombinant soluble mimetics of CCR5 have been synthesized and evaluated as a treatment method in acquired immunodeficiency syndrome $e^{60,61}$.

The inhibition of the CCR 5 and CXCR 4 could also have been by a cross-reacting antibody mechanism that could have existed, which needs to be evaluated. This could be a mechanism of shredding the receptors into the plasma from the endothelial cells either by synthesis or the existing receptors after the rose extract treatment. The results are preliminary, with results involving minimal samples only. Further large in-vitro tests and animal studies need to be performed to study the immune actions, and the side effects profile of the extract also needs to be evaluated. Nevertheless, this is the first study showing the benefits of rose extract treatment at the molecular level. Further studies need to be performed to assess the help of the extract at the cellular and clinical levels.

\section{CONCLUSIONS}

The rose extract increases the secretion of CCR5 by the endothelial cells, and CCR4 levels were not changed, but it prevents the reduction in the levels of CXCR4 with hypoxia treatment. Further large in-vitro and in-vivo studies are required for the evaluation of immune modulation by the rose extract.

\section{ABBREVIATIONS}

CCR: CC-Chemokine Receptor

\section{ACKNOWLEDGMENTS}

None.

\section{AUTHOR'S CONTRIBUTIONS}

MCA conceived the idea and method, designed the study, interpreted results and wrote the paper. EM 

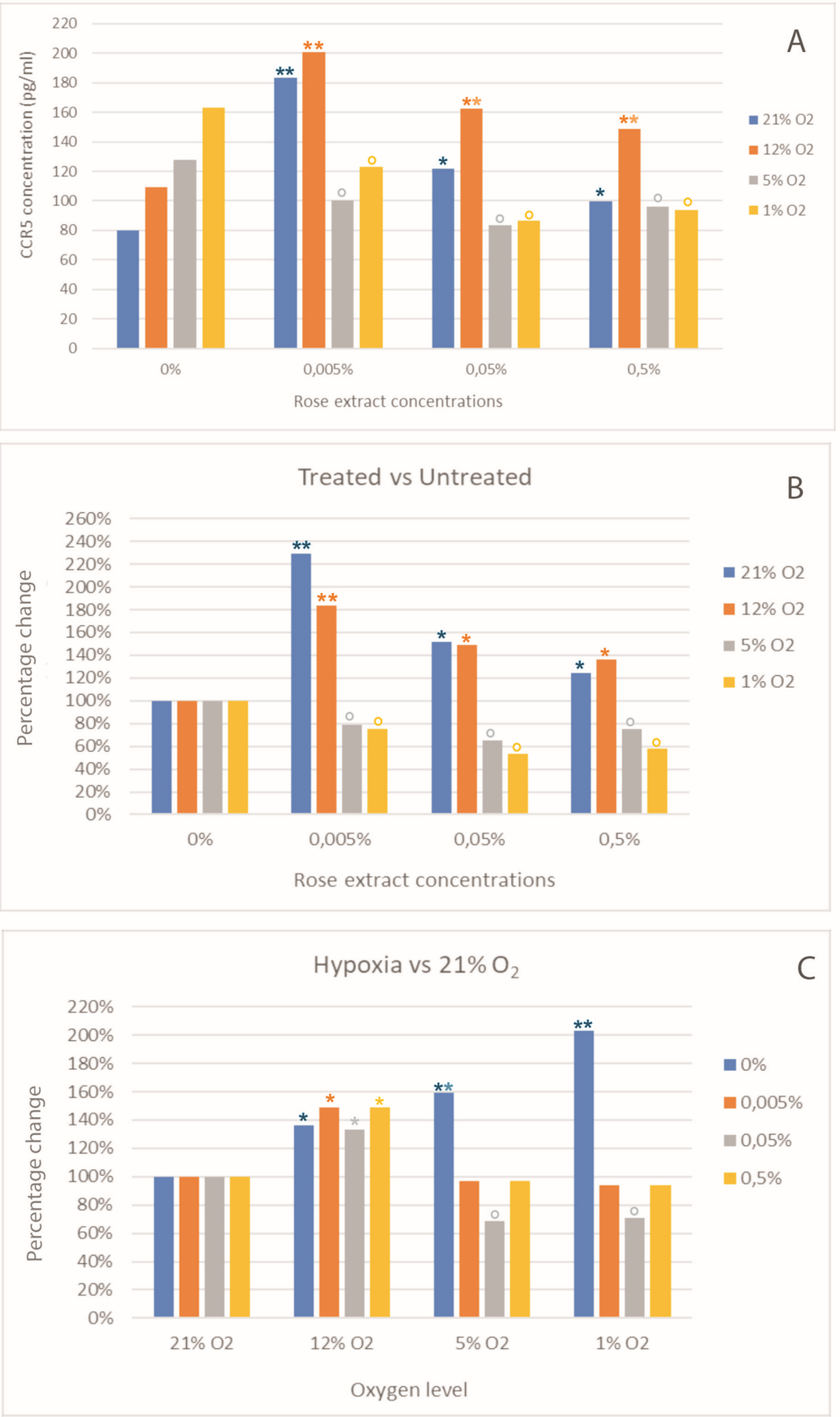

Figure 3: Quantification of human CCR5 in the samples. Panel A shows the results of concentrations changes in CCR5 levels after treatment of various concentrations of rose extract $(0.005,0.05$ and 0.5 percent $v / v$ of rose extract) and various degrees of hypoxia. Panel B shows the changes in percentage of CCR5 compared to baseline (Zero percent rose concentrations). Panel $C$ shows changes CCR5 under various degrees of hypoxia and rose extract concentrations. ${ }^{*}$ indicates an increase in value from baseline, ${ }^{O}$ indicates a decrease in value from baseline. 


\begin{tabular}{|c|c|c|c|c|c|}
\hline \multirow[b]{2}{*}{$\begin{array}{l}\text { Oxygen } \\
\text { level (\%) }\end{array}$} & \multicolumn{3}{|c|}{ amples } & \multicolumn{2}{|c|}{$\begin{array}{l}\text { Change } \\
\text { Percentage }\end{array}$} \\
\hline & $\begin{array}{c}\text { Rose extract } \\
\text { concentration } \\
(\%)\end{array}$ & $\begin{array}{c}\text { Absorbance } \\
\text { without blank (450 } \\
\mathrm{nm})\end{array}$ & $\begin{array}{c}\text { CXCR4 } \\
\text { concentration } \\
(\mathrm{pg} / \mathrm{mL})\end{array}$ & $\begin{array}{c}\text { Treated } \\
\text { vs. untreated } \\
(\%)\end{array}$ & $\begin{array}{l}\text { Hypoxia } \\
\text { vs. } \\
21 \% \mathrm{O}_{2}(\%)\end{array}$ \\
\hline 21 & 0 & 4.9 & 2190.1 & 100 & 100 \\
\hline 12 & 0 & 4.672 & 2021.2 & 100 & 92.3 \\
\hline 21 & 0.5 & 4.504 & 1905.7 & 87 & 100 \\
\hline 12 & 0.5 & 4.691 & 2034.8 & 100.7 & 106.8 \\
\hline 21 & 0.05 & 5.008 & 2275.9 & 103.9 & 100 \\
\hline 12 & 0.05 & 4.619 & 1984.3 & 98.2 & 87.2 \\
\hline 21 & 0.005 & 4.757 & 2082.9 & 95.1 & 100 \\
\hline 12 & 0.005 & 4.837 & 2142.4 & 106 & 102.9 \\
\hline 5 & 0 & 4.556 & 1940.6 & 100 & 88.6 \\
\hline 1 & 0 & 4.312 & 1781.8 & 100 & 81.4 \\
\hline 5 & 0.5 & 4.98 & 2253.2 & 116.1 & 118.2 \\
\hline 1 & 0.5 & 4.466 & 1880.3 & 105.5 & 98.7 \\
\hline 5 & 0.05 & 4.126 & 1668.8 & 86 & 73.3 \\
\hline 1 & 0.05 & 4.317 & 1784.6 & 100.2 & 78.4 \\
\hline 5 & 0.005 & 4.423 & 1852.7 & 95.5 & 88.9 \\
\hline 1 & 0.005 & 4.304 & 1776.7 & 99.7 & 85.3 \\
\hline
\end{tabular}

prepared the methods' protocol, performed the tests and derived the results. All authors read and approved the final manuscript.

\section{FUNDING}

None.

\section{AVAILABILITY OF DATA AND MATERIALS}

Data and materials used and/or analyzed during the current study are available from the corresponding author on reasonable request.

\section{ETHICS APPROVAL AND CONSENT TO PARTICIPATE}

Not applicable.

\section{CONSENT FOR PUBLICATION}

Not applicable.

\section{COMPETING INTERESTS}

The authors declare that they have no competing interests.

\section{REFERENCES}

1. Vangelista L, Vento $S$. The Expanding Therapeutic Perspective of CCR5 Blockade. Front Immunol. 2018;8:1981. PMID: 29375583. Available from: 10.3389/fimmu.2017.01981.

2. CCR5 Disruption Using a Novel CCR5-Specific MegaTAL Nuclease Confers High-Level Resistance To HIV Infection in Human T Cells; 2014. Available from: 10.1016/S1525-0016(16)35764-1.

3. Mario M, Laura M. CCR5 expression reduces T-tropic HIV-1 strain infection by forming CD4/CXCR4/CCR5 oligomers. Front Immunol. 2013;4:4. Available from: 10.3389/conf.fimmu.2013. 02.00615 .

4. García-Cuesta EM, Santiago CA, Vallejo-Díaz J, Juarranz $\mathrm{Y}$, Rodríguez-Frade JM, Mellado $M$. The Role of the CXCL12/CXCR4/ACKR3 Axis in Autoimmune Diseases. Front Endocrinol (Lausanne). 2019;10:585. PMID: 31507535. Available from: 10.3389/fendo.2019.00585.

5. Jiao X, Nawab O, Patel T, Kossenkov AV, Halama N, Jaeger D. Recent Advances Targeting CCR5 for Cancer and Its Role in Immuno-Oncology. Cancer Res. 2019;79(19):4801-7. PMID: 31292161. Available from: 10.1158/0008-5472.CAN-19-1167.

6. Glass WG, McDermott DH, Lim JK, Lekhong S, Yu SF, Frank WA. CCR5 deficiency increases risk of symptomatic West Nile virus infection. J Exp Med. 2006;203(1):35-40. PMID: 16418398. Available from: $10.1084 /$ jem.20051970.

7. Ryst EVD. Maraviroc - A CCR5 Antagonist for the Treatment of HIV-1 Infection. Front Immunol. 2015;6:277. PMID: 26097475. 


\begin{tabular}{|c|c|c|c|c|}
\hline $\begin{array}{c}\text { Standard } \\
\text { concentration } \\
(\mathrm{pg} / \mathrm{ml})\end{array}$ & \multicolumn{2}{|c|}{ Absorbance - blank } & \multirow{2}{*}{$\begin{array}{c}\text { Absorbance } \\
\text { average }\end{array}$} & $\begin{array}{c}\text { Standard } \\
\text { deviation }\end{array}$ \\
\cline { 2 - 3 } & Replicate 1 & Replicate 2 & 6.967 & 0.291 \\
\hline 5000 & 7.257 & 6.676 & 6.254 & 0.059 \\
\hline 2500 & 5.313 & 5.194 & 3.358 & 0.130 \\
\hline 1250 & 3.487 & 3.228 & 1.751 & 0.204 \\
\hline 625 & 1.955 & 1.547 & 0.846 & 0.088 \\
\hline 312.5 & 0.934 & 0.758 & 0.382 & 0.048 \\
\hline 156.25 & 0.43 & 0.334 & 0.176 & 0.026 \\
\hline 78.13 & 0.201 & 0.15 & \\
\hline \multicolumn{5}{|c|}{ Sandrdarre(s) } \\
\end{tabular}

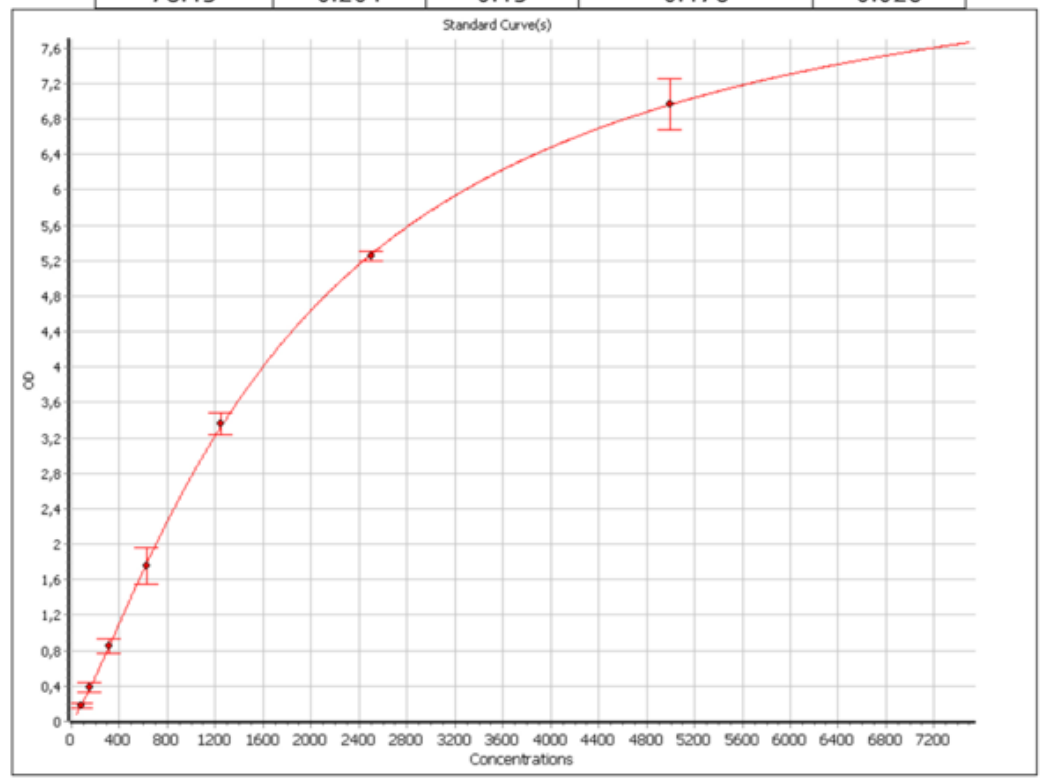

Figure 4: Standard curve of human CXCR4 ELISA assay which shows the standard CXCR4 concentration values against absorbance observed at $21 \% \mathrm{O}_{2}$.

Available from: 10.3389/fimmu.2015.00277.

8. Arokiaraj MC, Menesson E. Rose Extract Treatment on the CD4+ T lymphocytes. BioRxiv. 2021;Available from: 10.1101/ 2021.04.06.438604.

9. Malvoisin E, Livrozet JM, Makloufi D, Vincent N. Soluble chemokine receptor CXCR4 is present in human sera. Anal Biochem. 2011;414(2):202-7. PMID: 21440527. Available from: 10.1016/j.ab.2011.03.022.

10. Tsimanis A, Kalinkovich A, Bentwich Z. Soluble chemokine CCR5 receptor is present in human plasma. Immunol Lett. 2005;96(1):55-61. PMID: 15585308. Available from: 10.1016/j. imlet.2004.07.014.

11. https://www.abbkine.com/product/human-cc-chemokine-re ceptor-5-ccr5-elisa-kit-kte62546/.

12. Kohl TO, Ascoli CA. Immunometric Double-Antibody Sandwich Enzyme-Linked Immunosorbent Assay. Cold Spring Harb Protoc. 2017;Available from: 10.1101/pdb.prot093724.

13. Stanker LH, Hnasko RM. A Double-Sandwich ELISA for Identification of Monoclonal Antibodies Suitable for Sandwich Immunoassays. Methods Mol Biol. 2015;1318:69-78. PMID: 26160565. Available from: 10.1007/978-1-4939-2742-5 7 .

14. Hnasko R. ELISA. Methods Mol Biol. 2015;(1318):43-50. PMID: 26160562. Available from: 10.1007/978-1-4939-2742-5 4.

15. Siddiqui J, Remick DG. Improved sensitivity of colorimetric compared to chemiluminescence ELISAs for cytokine assays. J Immunoassay Immunochem. 2003;24(3):273-83. PMID: 12953972. Available from: $10.1081 /$ IAS- 120022937.
16. https://www.elabscience.com/phuman $\% C 2 \% A 0 c x c r 4$ (chem okine_c_x_c_motif_receptor_4)_elisa_kit-19984.html.

17. Lapham CK, Romantseva T, Petricoin E, King LR, Manischewitz J, Zaitseva MB. CXCR4 heterogeneity in primary cells: possible role of ubiquitination. J Leukoc Biol. 2002;72(6):1206-14. PMID: 12488503. Available from: 10.1189/jlb.72.6.1206.

18. Barmania F, Pepper MS. C-C chemokine receptor type five (CCR5): An emerging target for the control of HIV infection. Applied \& Translational Genomics. 2013;2(1):3-16. Available from: 10.1016/j.atg.2013.05.004.

19. Clark WR, Winchester JF. Middle molecules and smallmolecular-weight proteins in ESRD: properties and strategies for their removal. Adv Ren Replace Ther. 2003;10(4):270-8. PMID: 14681858. Available from: 10.1053/j.arrt.2003.11.004.

20. Arokiaraj MC, Menesson E. Novel anti-inflammatory and immunomodulation effects of Rose on the endothelium in normal and hypoxic invitro conditions. Angiol Cir Vasc. 2019;15(4):238-48.

21. Ferain T, Hoveyda H, Ooms F, Schols D, Bernard J, Fraser G. Agonist-induced internalization of CC chemokine receptor 5 as a mechanism to inhibit HIV replication. J Pharmacol Exp Ther. 2011;337(3):655-62. PMID: 21389095. Available from: 10.1124/jpet.111.179622.

22. Saita $Y$, Kodama E, Orita M, Kondo M, Miyazaki T, Sudo K. Structural basis for the interaction of CCR5 with a small molecule, functionally selective CCR5 agonist. J Immunol. 2006;177(5):3116-22. PMID: 16920949. Available from: 10 . 4049/jimmunol.177.5.3116. 

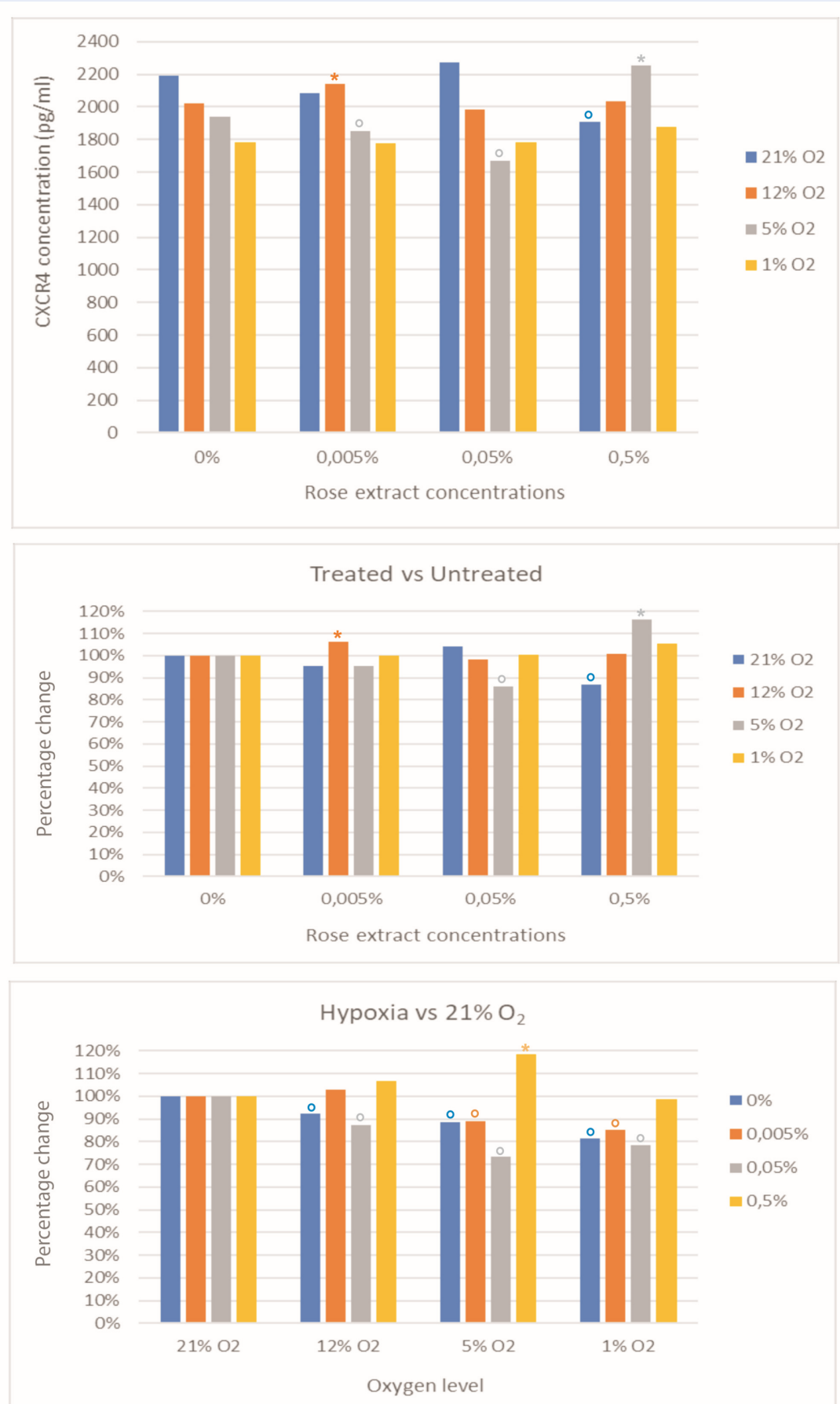

Figure 5: Quantification of human CXCR4 in the samples. Panel A shows the results of concentrations changes in CXCR4 levels after treatment of various concentrations of rose extract $(0.005,0.05$ and 0.5 percent $\mathrm{v} / \mathrm{v}$ of rose extract) and various degrees of hypoxia. Panel B shows the changes in percentage of CXCR4 compared to baseline (Zero percent rose concentrations). Panel $\mathrm{C}$ shows changes CXCR4 under various degrees of hypoxia and rose extract concentrations. ${ }^{*}$ indicates an increase in value from baseline, ${ }^{O}$ indicates a decrease in value from baseline. 
23. Venkatesan S, Rose JJ, Lodge R, Murphy PM, Foley JF. Distinct mechanisms of agonist-induced endocytosis for human chemokine receptors CCR5 and CXCR4. Mol Biol Cell. 2003;14(8):3305-24. PMID: 12925765. Available from: 10. 1091/mbc.e02-11-0714.

24. Kellenberger E, Springael JY, Parmentier M, Hachet-Haas M, Galzi JL, Rognan D. Identification of nonpeptide CCR5 receptor agonists by structure-based virtual screening. J Med Chem. 2007;50(6):1294-303. PMID: 17311371. Available from: 10.1021/jm061389p.

25. Lefrançois M, Lefebvre MR, Saint-Onge G, Boulais PE, Lamothe S, Leduc R. Agonists for the Chemokine Receptor CXCR4. ACS Med Chem Lett. 2011;2(8):597-602. PMID: 21841963. Available from: $10.1021 / \mathrm{ml} 200084 \mathrm{n}$.

26. Tchernychev B, Ren Y, Sachdev P, Janz JM, Haggis L, O'Shea A. Discovery of a CXCR4 agonist pepducin that mobilizes bone marrow hematopoietic cells. Proc Natl Acad Sci USA. 2010;107(51):22255-9. PMID: 21139054. Available from: 10. 1073/pnas.1009633108.

27. Mishra RK, Shum AK, Platanias LC, Miller RJ, Schiltz GE. Discovery and characterization of novel small-molecule CXCR4 receptor agonists and antagonists. Sci Rep. 2016;6(1):30155. PMID: 27456816. Available from: 10.1038/srep30155.

28. Wang SW, Liu SC, Sun HL, Huang TY, Chan CH, Yang CY. CCL5/CCR5 axis induces vascular endothelial growth factormediated tumor angiogenesis in human osteosarcoma microenvironment. Carcinogenesis. 2015;36(1):104-14. PMID: 25330803. Available from: 10.1093/carcin/bgu218.

29. Hawila E, Razon H, Wildbaum G, Blattner C, Sapir Y, Shaked Y. CCR5 Directs the Mobilization of CD11b+Gr1+Ly6Clow Polymorphonuclear Myeloid Cells from the Bone Marrow to the Blood to Support Tumor Development. Cell Rep. 2017;21(8):2212-22. PMID: 29166611. Available from: 10. 1016/j.celrep.2017.10.104.

30. Singh SK, Mishra MK, Eltoum IA, Bae S, Lillard JW, Singh R. CCR5/CCL5 axis interaction promotes migratory and invasiveness of pancreatic cancer cells. Sci Rep. 2018;8(1):1323. PMID: 29358632. Available from: 10.1038/s41598-018-19643-0.

31. Suffee $N$, Hlawaty $H$, Meddahi-Pelle A, Maillard L, Louedec L, Haddad O. RANTES/CCL5-induced pro-angiogenic effects depend on CCR1, CCR5 and glycosaminoglycans. Angiogenesis. 2012;15(4):727-44. PMID: 22752444. Available from: 10.1007/s10456-012-9285-x.

32. Zagzag D, Lukyanov $Y$, Lan L, Ali MA, Esencay M, Mendez O. Hypoxia-inducible factor 1 and VEGF upregulate CXCR4 in glioblastoma: implications for angiogenesis and glioma cell invasion. Lab Invest. 2006;86(12):1221-32. PMID: 17075581. Available from: 10.1038/labinvest.3700482.

33. Hardison JL, Wrightsman RA, Carpenter PM, Kuziel WA, Lane TE, Manning JE. The CC chemokine receptor 5 is important in control of parasite replication and acute cardiac inflammation following infection with Trypanosoma cruzi. Infect Immun. 2006;74(1):135-43. PMID: 16368966. Available from: 10.1128/ IAI.74.1.135-143.2006.

34. Batista AM, Alvarado-Arnez LE, Alves SM, Melo G, Pereira IR Ruivo LA. Genetic Polymorphism at CCL5 Is Associated With Protection in Chagas' Heart Disease: Antagonistic Participation of CCR $1+$ and CCR5 + Cells in Chronic Chagasic Cardiomyopathy. Front Immunol. 2018;9:615. PMID: 29696014. Available from: 10.3389/fimmu.2018.00615.

35. Liang W, Gorr MW, Insel PA. CCR5 antagonism as a potential therapeutic approach for cardiac fibrosis. The FASEB Journal. 2018;(32):839.2-839.2. Available from: 10.1096/fasebj.2018.32. 1_supplement.839.2.

36. Maguire JJ, Jones KL, Kuc RE, Clarke MC, Bennett MR, Davenport AP. The CCR5 chemokine receptor mediates vasoconstriction and stimulates intimal hyperplasia in human vessels in vitro. Cardiovasc Res. 2014;101(3):513-21. PMID: 24323316. Available from: $10.1093 / \mathrm{cvr} / \mathrm{cvt} 333$.

37. Zernecke A, Liehn EA, Gao JL, Kuziel WA, Murphy PM, Weber C. Deficiency in CCR5 but not CCR1 protects against neointima formation in atherosclerosis-prone mice: involvement of IL-
10. Blood. 2006;107(11):4240-3. PMID: 16467202. Available from: 10.1182/blood-2005-09-3922.

38. Gong $X$, Feng H, Zhang S, Yu Y, Li J, Wang J. Increased expression of CCR5 in experimental autoimmune myocarditis and reduced severity induced by anti-CCR5 monoclonal antibody. Mol Cell Cardiol. 2007;42(4):781-91. PMID: 17362985. Available from: 10.1016/j.yjmcc.2007.02.003.

39. Pyo RT, Sui J, Dhume A, Palomeque J, Blaxall BC, Diaz G. CXCR4 modulates contractility in adult cardiac myocytes. J Mol Cell Cardiol. 2006;41(5):834-44. PMID: 17010372. Available from: 10.1016/j.yjmcc.2006.08.008.

40. Döring $Y$, Noels $H$, van der Vorst EP, Neideck C, Egea V, Drechsler M. Vascular CXCR4 Limits Atherosclerosis by Maintaining Arterial Integrity: Evidence From Mouse and Human Studies. Circulation. 2017;136(4):388-403. PMID: 28450349. Available from: 10.1161/CIRCULATIONAHA.117.027646.

41. Shen B, Li J, Gao L, Zhang J, Yang B. Role of CC-chemokine receptor 5 on myocardial ischemia-reperfusion injury in rats. Mol Cell Biochem. 2013;378(1-2):137-44. PMID: 23456481. Available from: 10.1007/s11010-013-1604-z.

42. Muntinghe FL, Verduijn M, Zuurman MW, Grootendorst DC Carrero JJ, Qureshi AR. CCR5 deletion protects against inflammation-associated mortality in dialysis patients. J Am Soc Nephrol. 2009;20(7):1641-9. PMID: 19389855. Available from: 10.1681/ASN.2008040432.

43. Wen J, Zhang JQ, Huang W, Wang Y. SDF- $1 \alpha$ and CXCR4 as therapeutic targets in cardiovascular disease. Am J Cardiovasc Dis. 2012;2(1):20-8. PMID: 22254210.

44. Mencarelli A, Cipriani S, Francisci D, Santucci L, Baldelli F, Distrutti E. Highly specific blockade of CCR5 inhibits leukocyte trafficking and reduces mucosal inflammation in murine colitis. Sci Rep. 2016;6(1):30802. PMID: 27492684. Available from: $10.1038 /$ srep30802.

45. Whittall T, Wang Y, Younson J, Kelly C, Bergmeier L, Peters B. Interaction between the CCR5 chemokine receptors and $\mathrm{mi}$ crobial HSP70. Eur J Immunol. 2006;36(9):2304-14. PMID: 16909434. Available from: 10.1002/eji.200635953.

46. Ma B, Liu W, Homer RJ, Lee PJ, Coyle AJ, Lora JM. Role of CCR5 in the pathogenesis of IL-13-induced inflammation and remodeling. J Immunol. 2006;176(8):4968-78. PMID: 16585593. Available from: 10.4049/jimmunol.176.8.4968.

47. Konrad FM, Meichssner N, Bury A, Ngamsri KC, Reutershan J. Inhibition of SDF-1 receptors CXCR4 and CXCR7 attenuates acute pulmonary inflammation via the adenosine $\mathrm{A} 2 \mathrm{~B}$ receptor on blood cells. Cell Death Dis. 2017;8(5):e2832. PMID: 28542132. Available from: 10.1038/cddis.2016.482.

48. Kawaguchi N, Zhang TT, Nakanishi T. Involvement of CXCR4 in Normal and Abnormal Development. Cells. 2019;8(2):185. PMID: 30791675 . Available from: 10.3390/cells8020185.

49. Amsellem V, Lipskaia L, Abid S, Poupel L, Houssaini A, Quarck R. CCR5 as a treatment target in pulmonary arterial hypertension. Circulation. 2014;130(11):880-91. PMID: 24993099. Available from: 10.1161/CIRCULATIONAHA.114.010757.

50. Farkas D, Kraskauskas D, Drake Jl, et al. CXCR4 inhibition ameliorates severe obliterative pulmonary hypertension and accumulation of C-kit+ cells in rats. PLoS One. 2014;9(2):e89810. Available from: 10.1371/journal.pone.0089810.

51. Li XQ, Zhang ZL, Tan WF, Sun XJ, Ma H. Down-Regulation of CXCL12/CXCR4 Expression Alleviates Ischemia-ReperfusionInduced Inflammatory Pain via Inhibiting Glial TLR4 Activation in the Spinal Cord. PLoS One. 2016;11(10):e0163807. PMID: 27760212. Available from: 10.1371/journal.pone.0163807.

52. Sorce S, Myburgh R, Krause KH. The chemokine receptor CCR5 in the central nervous system. Prog Neurobiol. 2011;93(2):297-311. PMID: 21163326. Available from: 10. 1016/j.pneurobio.2010.12.003.

53. Li T, Zhu J. Entanglement of CCR5 and Alzheimer's Disease. Front Aging Neurosci. 2019;11:209. PMID: 31447666. Available from: 10.3389/fnagi.2019.00209.

54. Maung R, Hoefer MM, Sanchez AB, Sejbuk NE, Medders KE, Desai MK. CCR5 knockout prevents neuronal injury and be- 
havioral impairment induced in a transgenic mouse model by a CXCR4-using HIV-1 glycoprotein 120 . J Immunol. 2014;193(4):1895-910. PMID: 25031461. Available from: 10.4049/jimmunol.1302915.

55. Joy MT, Assayag EB, Shabashov-Stone D, Liraz-Zaltsman $S$ Mazzitelli J, Arenas M. CCR5 Is a Therapeutic Target for Recovery after Stroke and Traumatic Brain Injury. Cell. 2019;176(5). PMID: 30794775. Available from: 10.1016/j.cell.2019.01.044.

56. Li P, Wang L, Zhou Y, Gan Y, Zhu W, Xia Y. C-C Chemokine Receptor Type 5 (CCR5)-Mediated Docking of Transferred Tregs Protects Against Early Blood-Brain Barrier Disruption After Stroke. J Am Heart Assoc. 2017;6(8):e006387. PMID: 28768648. Available from: 10.1161/JAHA.117.006387.

57. Pradhan P, Pandey A, Mishra A, Gupta P, Tripathi P, Menon M, et al. Uncanny similarity of unique inserts in the 2019-nCoV spike protein to HIV-1 gp120 and Gag. BioRxiv. 2020;Available from: 10.1101/2020.01.30.927871.
58. Tsimanis A, Kalinkovich A, Bentwich Z. Soluble chemokine CCR5 receptor is present in human plasma. Immunol Lett. 2005;96(1):55-61. PMID: 15585308. Available from: 10.1016/j. imlet.2004.07.014.

59. Malvoisin E, Livrozet JM, Makloufi D, Vincent N. Soluble chemokine receptor CXCR4 is present in human sera. Anal Biochem. 2011;414(2):202-7. PMID: 21440527. Available from: 10.1016/j.ab.2011.03.022.

60. Kurbatska V, Rudevica Z, Tsimanis A, Leonciks A. Recombinant soluble CCR5 AND CXCR4 chemokine receptors as antiHIV drug targets. Retrovirology. 2010;7(P44). Available from: 10.1186/1742-4690-7-S1-P44.

61. Hajduczki A, Bundoc V, Berger E. Developing soluble mimetics of the chemokine receptor CCR5 for the study of HIV Env/receptor interactions (CCR6P. 216. 2015;194(1 Supplement):187.3. 